\title{
Pengaruh obat kumur beralkohol terhadap laju aliran saliva dan pH saliva
}

\author{
${ }^{1}$ Feiby Rawung \\ ${ }^{2}$ Jane Wuisan \\ ${ }^{3}$ Michael A. Leman
}

\author{
${ }^{\mathbf{1}}$ Kandidat Skripsi Program Studi Pendidikan Dokter Gigi Fakultas Kedokteran \\ ${ }^{2}$ Bagian Farmakologi dan Terapi Fakultas Kedokteran \\ ${ }^{3}$ Program Studi Pendidikan Dokter Gigi Fakultas Kedokteran \\ Universitas Sam Ratulangi Manado \\ Email: feiby_rawung@yahoo.com
}

\begin{abstract}
Mouthwash is one of the accessible oral healthcare and practical for use by the community. Various commercial products contain more than one active ingredient; the most common one is alcohol with varied concentrations from $6 \%$ to $26 \%$. Mouthwash with high concentration of alcohol can cause some effects to some users, like burning and dry sensation of the oral mucosa. Dry oral mucosa caused by reduced saliva production will be more susceptible to irritation. Reduced amount of saliva also causes lower oral $\mathrm{pH}$ which leads to increased growth of cariogenic bacteria. This study was aimed to investigate the influence of alcoholic mouthwash to salivary flow and salivary $\mathrm{pH}$. This was a quasi-experiment study with before and after treatment groups. The population study was students of Dental Medical Education Program of Medical Faculty of University of Sam Ratulangi, Manado, batch 2012, with a total of 30 respondents obtained by using purposive sampling method. The $\mathrm{T}$ test showed that salivary flow rate before and after treatment had no significant difference ( $p$ $>0.05$ ) based on $T$ test. Moreover, the Wilcoxon test showed that there was no significant difference of salivary $\mathrm{pH}$ between before and after treatment $(\mathrm{p}>0.05)$. Conclusion: There was no effect of rinsing with alcoholic mouthwash on salivary flow and salivary $\mathrm{pH}$.
\end{abstract}

Keywords: alcoholic mouthwash, salivary flow rate, salivary $\mathrm{pH}$

\begin{abstract}
Abstrak: Obat kumur merupakan salah satu produk perawatan kesehatan gigi dan mulut yang mudah diperoleh dan praktis digunakan sendiri oleh masyarakat. Berbagai produk komersial mengandung lebih dari satu bahan aktif; salah satunya yaitu alkohol dengan konsentrasi bervariasi dari $6 \%$ hingga 26,9\%. Kandungan alkohol yang tinggi dapat menimbulkan efek bagi sebagian pengguna, seperti sensasi terbakar dan kering di area mukosa mulut disebabkan berkurangnya saliva yang memudahkan terjadinya iritasi. Berkurangnya saliva juga menyebabkan $\mathrm{pH}$ mulut rendah sehingga pertumbuhan bakteri kariogenik meningkat. Penelitian ini bertujuan untuk mengetahui adanya pengaruh obat kumur beralkohol terhadap laju aliran saliva dan $\mathrm{pH}$ saliva. Jenis penelitian ialah eksperimen semu dengan kelompok sebelum dan sesudah perlakuan. Populasi penelitian yaitu mahasiswa Angkatan Tahun 2012 Program Studi Pendidikan Dokter Gigi, Fakultas Kedokteran, Universitas Sam Ratulangi Manado yang berjumlah 30 responden, diperoleh dengan purposive sampling. Hasil uji $\mathrm{T}$ berpasangan mennunjukkan data laju aliran saliva sebelum dan sesudah perlakuan tidak memiliki perbedaan bermakna $(p>0,05)$. Berdasarkan uji Wilcoxon, data $\mathrm{pH}$ saliva sebelum dan sesudah perlakuan tidak memiliki perbedaan bermakna $(p>0,05)$. Simpulan: Tidak terdapat pengaruh berkumur dengan obat kumur beralkohol terhadap laju aliran saliva dan $\mathrm{pH}$ saliva.
\end{abstract}

Kata kunci: obat kumur beralkohol, laju aliran saliva, $\mathrm{pH}$ saliva 
Obat kumur merupakan salah satu produk perawatan kesehatan gigi dan mulut yang dikategorikan sebagai obat bebas tanpa peresepan tenaga medis, sehingga mudah diperoleh dan praktis digunakan sendiri oleh masyarakat. Obat kumur memiliki dua fungsi, yaitu fungsi terapeutik dan kosmetik. Fungsi terapeutik digunakan untuk mengurangi plak, radang gusi, karies gigi, dan stomatitis, sedangkan fungsi kosmetik dapat diformulasikan untuk mengurangi bau mulut melalui penggunaan antimikroba dan zat perasa. ${ }^{1}$

Masyarakat dengan mudah membeli dan menggunakan obat kumur tanpa mengetahui secara pasti komposisi yang dapat menimbulkan efek samping pada rongga mulut. Berbagai produk secara komersial mengandung lebih dari satu bahan aktif dan salah satu yang paling umum ditemukan yaitu alcohol. ${ }^{1}$

Beberapa macam konsentrasi alkohol yang tersedia mulai dari $6 \%$ hingga $26,9 \%,{ }^{2}$ dan merek yang sering dijumpai di pasaran mengandung lebih dari $20 \%$. Fungsi alkohol dalam obat kumur dapat melarutkan bahan aktif lainnya berupa minyak esensial, dan juga berperan sebagai bahan pengawet dalam larutan. ${ }^{1}$

Kombinasi alkohol dengan minyak esensial terbukti memberikan efek antimikroba yang signifikan terhadap bakteri dalam biofilm setelah berkumur selama 30 detik. $^{3}$ Penelitian Fischman et al. ${ }^{4}$ menunjukkan bahwa penggunaan obat kumur beralkohol dengan minyak essensial memiliki potensi terhadap iritasi mulut dan perubahan fisiologik mukosa pada penderita xerostomia. Kandungan alkohol yang tinggi dalam obat kumur juga menimbulkan efek bagi sebagian pengguna, seperti sensasi terbakar dalam mulut dan terasa kering di area mukosa mulut. ${ }^{5,6}$ McCullough dan Farah $^{7}$ menyatakan bahwa terdapat efek merugikan dalam rongga mulut yang dapat timbul dari kandungan alkohol tinggi (lebih dari 20\%) dalam obat kumur seperti epithelial detachment, keratosis, ulserasi mukosa, gingivitis, bintik merah, serta nyeri dalam mulut. ${ }^{7}$

Mukosa mulut menjadi kering disebab- kan oleh berkurangnya saliva. Selaput lendir yang mengering akan lebih mudah mengalami iritasi dan infeksi dalam mulut. Keadaan ini disebabkan oleh tidak ada daya lubrikasi dan proteksi yang cukup dari saliva. Kekeringan mulut menyebabkan fungsi pembersihan dari saliva berkurang, sehingga dapat terjadi radang kronis di selaput lendir yang disertai keluhan nyeri atau terasa seperti terbakar. ${ }^{8}$

Jumlah saliva yang berkurang juga menyebabkan $\mathrm{pH}$ mulut rendah, karena terjadi penurunan jumlah elektrolit dari kelenjar saliva yang menentukan derajat keasaman. Bila $\mathrm{pH}$ pada rongga mulut rendah, susunan mikroflora dalam mulut mengalami perubahan salah satunya pertumbuhan bakteri kariogenik seperti Streptococcus mutans, Lactobacillus, dan Candida albicans meningkat. Akibatnya penderita mulut kering lebih rentan terhadap infeksi dan penyakit mulut. ${ }^{8}$

Penelitian Enberg et al. ${ }^{9}$ menunjukkan bahwa setelah mengonsumsi minuman beralkohol dosis tinggi setelah terkena paparan jangka pendek dapat menyebabkan penurunan aliran saliva dan jumlah elektrolit dalam saliva secara bermakna.

Berdasarkan data di atas, penulis melakukan penelitian mengenai pengaruh kandungan alkohol dalam obat kumur terhadap laju aliran saliva dan $\mathrm{pH}$ saliva.

\section{BAHAN DAN METODE PENELITIAN}

Jenis penelitian ini ialah eksperimental semu dengan rancangan kelompok sebelum dan sesudah pengujian (pre-test and posttest group design). Penelitian ini dilaksanakan di Program Studi Pendidikan Dokter Gigi Fakultas Kedokteran Universitas Sam Ratulangi Manado pada bulan Februari - Agustus tahun 2016. Sampel dalam penelitian ini diperoleh dengan menggunakan metode purposive sampling serta kriteria inklusi dan ekslusi. Kriteria inklusi ialah sebagai berikut: jenis kelamin laki-laki dan perempuan, usia 21 22 tahun, bersedia mengisi informed consent. Kriteria ekslusi ialah sebagai berikut: memiliki penyakit sistemik yang berpengaruh terhadap sekresi saliva dan 
mengonsumsi obat-obatan yang memiliki efek pada sekresi saliva. Data dari hasil pengukuran laju aliran saliva dan $\mathrm{pH}$ saliva diolah menggunakan program komputer Statistik 17.0 dengan uji T berpasangan dan uji Wilcoxon disajikan dalam bentuk tabel.

\section{HASIL PENELITIAN}

Karakteristik responden berdasarkan jenis kelamin menunjukkan responden lakilaki $(50 \%)$ sama banyak dengan responden perempuan $(50 \%)$ (Tabel 1).

Tabel 1. Distribusi responden penelitian berdasarkan jenis kelamin

\begin{tabular}{lcc}
\hline Jenis kelamin & N & $\begin{array}{c}\text { Frekuensi } \\
(\boldsymbol{\%})\end{array}$ \\
\hline Laki-laki & 15 & 50 \\
Perempuan & 15 & 50 \\
Total & 30 & 100 \\
\hline
\end{tabular}

Data laju aliran saliva sebelum dan sesudah perlakuan diuji normalitas menggunakan uji Saphiro-Wilk yang menunjukkan data berdistribusi secara normal $(p>0,05)$ (Tabel 2).

Tabel 2. Uji normalitas Shapiro-Wilk

\begin{tabular}{cc}
\hline Variabel & $\boldsymbol{P}$ \\
\hline Laju aliran saliva sebelum & 0,20 \\
Laju aliran saliva sesudah & 0,11 \\
\hline
\end{tabular}

Uji $\mathrm{T}$ berpasangan digunakan untuk mengetahui pengaruh obat kumur beralkohol terhadap laju aliran saliva berdasarkan nilai rerata antara sebelum dan sesudah perlakuan. Hasil uji T berpasangan menunjukkan bahwa tidak terdapat perbedaan bermakna antara data laju aliran saliva sebelum dengan data laju aliran saliva sesudah berkumur obat kumur beralkohol $(p>0,05)$ (Tabel 3).

Data $\mathrm{pH}$ saliva sebelum dan sesudah perlakuan diuji normalitas menggunakan uji Saphiro-Wilk. Hasil menunjukkan data $\mathrm{pH}$ saliva sebelum perlakuan berdistribusi secara tidak normal $(p<0,05)$, sedangkan data $\mathrm{pH}$ saliva sesudah perlakuan berdistribusi secara normal $(p>0,05)$ (Tabel 4).
Tabel 3. Uji $\mathrm{T}$ berpasangan rerata laju aliran saliva sebelum dan sesudah perlakuan berkumur dengan obat kumur berlakohol

\begin{tabular}{ccc}
\hline Variabel & Rerata \pm SD & $\boldsymbol{P}$ \\
\hline $\begin{array}{c}\text { Laju aliran } \\
\text { saliva sebelum } \\
\text { Laju aliran } \\
\text { saliva sesudah }\end{array}$ & $0,36 \pm 0,26$ & 0,96 \\
\hline
\end{tabular}

Tabel 4. Uji normalitas Shapiro-Wilk

\begin{tabular}{cc}
\hline Variabel & $\boldsymbol{P}$ \\
\hline pH saliva sebelum & 0,00 \\
pH saliva sesudah & 0,10 \\
\hline
\end{tabular}

Uji Wilcoxon digunakan untuk mengetahui pengaruh obat kumur beralkohol terhadap $\mathrm{pH}$ saliva berdasarkan nilai rerata antara sebelum dan sesudah perlakuan. Hasil uji Wilcoxon menunjukkan bahwa tidak terdapat perbedaan bermakna antara data $\mathrm{pH}$ saliva sebelum dengan data $\mathrm{pH}$ saliva sesudah berkumur obat kumur beralkohol $(p>0,05)$ (Tabel 5).

Tabel 5. Uji Wilcoxon rerata $\mathrm{pH}$ saliva sebelum dan sesudah perlakuan berkumur dengan obat kumur beralkohol

\begin{tabular}{ccc}
\hline Variabel & Rerata \pm SD & $\boldsymbol{P}$ \\
\hline pH saliva sebelum & $7,15 \pm 0,27$ & \\
pH saliva sesudah & $7,10 \pm 0,28$ & 0,63 \\
\hline
\end{tabular}

\section{BAHASAN}

Data hasil penelitian dari mahasiswa Program Studi Pendidikan Dokter Gigi Fakultas Kedokteran Universitas Sam Ratulangi Manado yang mengisi informed consent sesuai kriteria inklusi berjumlah 30 orang. Dilihat dari jenis kelamin, jumlah responden laki-laki sama banyak dengan jumlah responden perempuan.

Data laju aliran saliva sebelum dan sesudah perlakuan diuji normalitas dengan menggunakan uji Saphiro-Wilk dan hasil menunjukkan bahwa semua data berdistribusi normal, sehingga dapat dilanjutkan dengan uji parametrik yaitu uji $T$ berpasangan.

Uji $\mathrm{T}$ berpasangan dilakukan untuk melihat ada tidaknya pengaruh obat kumur 
beralkohol pada laju aliran saliva. Hasil analisis data menunjukkan nilai $p=0,96(p$ $>0,05$ ) yang berarti tidak terdapat perbedaan bermakna antara data laju aliran saliva sebelum dengan data laju aliran saliva sesudah berkumur dengan obat kumur beralkohol, sehingga dapat dikatakan berkumur dengan obat kumur beralkohol tidak memiliki pengaruh pada laju aliran saliva.

Data $\mathrm{pH}$ saliva sebelum dan sesudah perlakuan diuji normalitas dengan menggunakan uji Saphiro-Wilk dan hasil menunjukkan bahwa data $\mathrm{pH}$ saliva sebelum perlakuan berdistribusi tidak normal, sehingga uji parametrik $\mathrm{T}$ berpasangan tidak dapat digunakan maka dilanjutkan dengan uji non-parametrik yaitu uji Wilcoxon.

Uji Wilcoxon dilakukan untuk melihat ada tidaknya pengaruh obat kumur beralkohol pada $\mathrm{pH}$ saliva. Hasil analisis data menunjukkan nilai $p=0,63(p>0,05)$ yang berarti tidak terdapat perbedaan bermakna antara data $\mathrm{pH}$ saliva sebelum dan sesudah berkumur dengan obat kumur beralkohol, sehingga dapat dikatakan berkumur dengan obat kumur beralkohol tidak memiliki pengaruh pada $\mathrm{pH}$ saliva.

Dari hasil pengamatan didapatkan bahwa pada sebagian responden terjadi peningkatan laju aliran saliva dan sebagian lainnya terjadi penurunan laju aliran saliva setelah berkumur menggunakan obat kumur beralkohol. Peningkatan laju aliran saliva dapat diakibatkan oleh stimulasi mekanik, kimiawi, dan rangsangan sakit. ${ }^{10}$ Hal ini memungkinkan karena gerakan berkumur dan pengecapan rasa pahit dari alkohol serta pemanis dari sorbitol dalam larutan obat kumur masih berpengaruh terhadap sistem saraf otonom. Hal serupa terjadi dalam penelitian yang dilakukan oleh Anwar et al. ${ }^{11}$ yaitu kecepatan aliran saliva meningkat dengan adanya stimulasi mekanik (berkumur) dan pengecapan rasa pahit dari polifenol teh hijau. Rasa nyeri seperti sensasi terbakar yang timbul akibat dari kandungan alkohol juga menjadi salah satu penyebab rangsangan sakit yang dapat meningkatkan laju aliran saliva. ${ }^{5,6,10}$
Penurunan laju aliran saliva bisa terjadi karena beberapa faktor, seperti tingkat stres, aktivitas fisik, dan derajat dehidrasi. ${ }^{8,12}$

Hasil pengamatan juga didapatkan bahwa sebagian responden terjadi peningkatan $\mathrm{pH}$ saliva dan sebagian lainnya terjadi penurunan $\mathrm{pH}$ saliva setelah berkumur menggunakan obat kumur beralkohol. Dari hasil data yang diperoleh, nilai laju aliran saliva yang meningkat diikuti dengan naiknya angka $\mathrm{pH}$ saliva, sedangkan laju aliran saliva yang menurun diikuti dengan rendahnya angka $\mathrm{pH}$ saliva. Hal ini sesuai teori, bahwa kenaikkan $\mathrm{pH}$ saliva dapat terjadi seiring meningkatnya sekresi saliva karena mengandung jumlah ion bikarbonat yang tinggi. Sebaliknya, penurunan $\mathrm{pH}$ juga diakibatkan menurunnya sekresi saliva dikarenakan jumlah ion bikarbonat yang sedikit. ${ }^{8}$ Penelitian yang dilakukan oleh Marabessy ${ }^{13}$ menyimpulkan hal yang sama bahwa setiap peningkatan atau penurunan volume saliva diikuti dengan peningkatan dan penurunan $\mathrm{pH}$ saliva sebesar $78,5 \%$.

Data penelitian ini menunjukkan hasil yang berbeda-beda yaitu terdapat peningkatan dan penurunan pada laju aliran saliva dan $\mathrm{pH}$ saliva. Meskipun demikian, hasil analisis data menunjukkan bahwa tidak ada perbedaan bermakna antara laju aliran saliva dan $\mathrm{pH}$ saliva sebelum dan sesudah perlakuan. Penelitian yang dilakukan oleh Kerr et al. ${ }^{14}$ menunjukkan bahwa tidak terdapat perbedaan bermakna pada sekresi saliva antara pengguna obat kumur beralkohol dan yang tidak beralkohol. Penelitian serupa dilakukan oleh Rahim ${ }^{15}$ menunjukkan bahwa tidak terdapat perbedaan bermakna pada curah saliva antara pemakai obat kumur beralkohol dan yang tidak beralkohol.

\section{SIMPULAN}

Obat kumur beralkohol tidak memiliki pengaruh terhadap laju aliran saliva dan $\mathrm{pH}$ saliva.

\section{SARAN}

1. Perlu dilakukan penelitian lebih lanjut 
mengenai pengaruh obat kumur beralkohol terhadap laju aliran saliva dan $\mathrm{pH}$ saliva dalam peningkatan waktu pemakaian.

2. Perlu dilakukan penelitian lebih lanjut dengan menggunakan larutan pembanding atau obat kumur dengan merek bervariasi untuk melihat perbedaan laju aliran saliva dan $\mathrm{pH}$ saliva.

\section{DAFTAR PUSTAKA}

1. Crowley MM. Solutions, emulsions, suspensions, and extracts. In: Troy D, editor. Remington: The Science and the Practice of Pharmacy (21st ed). Philadelphia: Lippincott William \& Wilkins, 2006; p.751.

2. Schmlaz G, Bindslev DA. Biocompatibility of Dental Materials. Berlin: Springer Verlag, 2009; p. 273.

3. Foster JS, Pan PC, Kolenbrander PE. Effects of antimicrobial agents on oral biofilms in a saliva-conditioned flow cell. J Biofilms. 2004;1(1):5-12.

4. Fischman SL, Aguirre A, Charles CH. Use of essential oil-containing mouthrinses by xerostomic individuals: determination of potential for oral mucosal irritation. Am J Dent. 2004;17(1):23-6.

5. Toedt J, Darrell K, Cleef-Toedt KV. Chemical Composition of Everyday Products. London: Greenwood Press, 2005; p. 48-9.

6. Werner CW, Seymour RA. Are alcoholcontaining mouthwashes safe? $\mathrm{Br}$ Dent J. 2009;207(10): E19;488-9.

7. McCullough MJ, Farah CS. The role of alcohol in oral carcinogenesis with particular reference to alcoholcontaining mouthwashes. Aust Dent J. 2008;53:303-4.
8. Kidd, Edwina AM, Sally Joyston-Bechal. In: Sumawinata N, Yuwono L, editors. Sifat dasar karies gigi: penyakit dan penanganannya (Essentials of Dental Caries: disease and its management). Jakarta: EGC, 1991; p.1-17.

9. Enberg N, Alho H, Loimaranta V, Lenander-Lumikari M. Saliva flow rate, amylase activity, and protein and electrolyte concentrations in saliva after acute alcohol consumption. Oral Surg Oral Med Oral Pathol Oral Radiol Endod. 2001;92:292-8.

10. Amerangon AV. Ludah dan Kelenjar Ludah (terj.). Yogyakarta: Gadjah Mada University Press, 1992; p.1-7, 37-41.

11. Anwar DA, Supartinah AL, Handajani J. Efek berkumur ekstrak teh hijau (Camellia sinensis) terhadap derajat keasaman dan volume saliva penderita gingivitis. Indo J Dent. 2007;14(1):226.

12. Almeida PDV, Gregio AMT, Machado MAN, Lima AAS, Azevedo LR. Saliva composition and functions: A comprehensive review. JCDP. 2008;9(3):2-8.

13. Marasabessy FA. Hubungan volume dan pH saliva pada lansia [Skripsi]. Makassar: Universitas Hasanuddin; 2013.

14. Kerr AR, Katz RW, Ship JA. A comparison of the effects of 2 comercially available nonprescription mouthrinses on salivary flow rates and xerostomia. Quintessence Int. 2007;38(5):440 7.

15. Rahim NM. Perbedaan curah saliva tidak terstimulasi antara lanjut usia yang menggunakan obat kumur beralkohol dan obat kumur non alkohol [Skripsi]. Yogyakarta: Universitas Gadjah Mada; 2015. 